\title{
EL
}

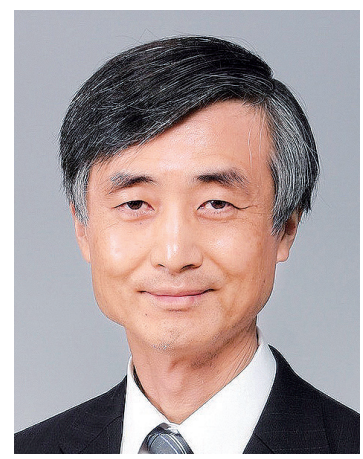

\section{伊達 勲}

岡山大学大学院脳神経外科教授/日本医学英語教育学会 理事長

1982 年

1988 年 1990 年

1991 年

1999 年

2003 年

2011 年〜

現在に至る

英語関連では

2003 年〜

2014 年〜

現在に至る
岡山大学医学部卒業

米国ニューヨーク州ロチェスター大学留学

岡山大学脳神経外科助手

岡山大学脳神経外科講師

岡山大学脳神経外科教授

岡山大学病院 副病院長

日本脳神経外科同時通訳団団長

日本医学英語教育学会理事長 


\section{データがあるなら論文にしよう : 英語論文執筆のポイント}

「研究をしてデー夕を得たら、英語で発表し、英語論文を書く。」これは、グローバル時代にあってどの医 学の分野でも必須のことである。しかしながら、「データがあるのに英語論文にならないままになっている、 あるいは英語論文として目の前に出てこないままになっている」という現実は、どこの医師も、どこの指導 者も日常経験していることであろう。これまで演者は約 350 の英語論文を執筆あるいは指導してきた。㧍そ らく同数かそれ以上の論文が世の中にでないままになっているような気がする。私が教室の医局員をどのよ うに励まして、英語でプレゼンをし、英語論文に仕上げるように指導してきたかについてお話しし、皆様の 参考にしていただければ幸いである。講演では、医学英語プレゼンと論文執筆のための以下の 10 箇条を提示 する。

1. なぜ医学英語論文を書くべきなのか。<読者の数の桁が違う、学会発表だけでは何も残らない、世界で認 められるなら英語>

2. 日本語のプレゼン（論文）を英語に訳すのか、はじめから英語で書くのか。<初めての論文は日本語でよ い、書き慣れてきたら最初から英語で書く>

3. 英語の native check は必要か。＼cjkstart絶対必要である>

4. 学会発表は英語論文執筆の大きなチャンス。〈抄録執筆はミニ論文執筆である>

5. 論文執筆に必要な基礎能力・知識とは。<医学英語特有表現を学ぼう、研究遂行能力と英文執筆能力は共 通である>

6. 一人で英語プレゼンテーションを練習するには。くシャドーイングとサイトラ＞

7. Materials and Methods と Results から書きはじめよう。く「マテメソ」と「結果」で論文の $50 \%$ を越え る、決まり文句が多い>

8. 普段から関連論文を集めて整理しょう。＜論文収集は研究を始めた時から、PDF だけでなく印刷も〉

9. スライド作りの基本を知ろう。＜7行ルール、背景の色と文字の色など $>$

10. 日本脳神経外科学会は同時通訳団を持っている。<同時通訳団の存在が学会員を刺激する>

私の講演が、皆椂が英語でプレゼンテーションをし、英語で論文を書くきっかけになることを祈念したい。 